\title{
ANCIENT AND MODERN USE OF PINE AT THE SITE OF CHINIKIHÁ, CHIAPAS, MÉXICO
}

\author{
FELIPE TRABANINO ${ }^{(1)} \&$ AURORA MURIENTE PASTRANA ${ }^{(2)}$
}

\begin{abstract}
:
Archaeobotanical remains of ocote pine have been recovered from different Classic Period (AD 300 - 900) Maya sites indicating use in ritual ceremonies and in household refuse for the fertilization of agricultural fields. Our results in the Palenque region, at the archaeological site of Chinikihá dating to Cal AD 620, suggest that there was no difference in the use of ocote in the residential units compared to that in the palace units. Ocote wood charcoal remains were found in ceremonial contexts, burials, household refuse deposited in home gardens, and patio's soils. We consider the ancien use of ocote pine alongside modern use of ocote in Guatemala and Chiapas, which has an economic importance with the cutting of pine sticks to sell in regional markets to use as torch for illumination and lighting daily cooking fires.

Keywords: Pinus, anthracology, Palenque, Nahá.

Resumen:

Uso moderno y antiguo del pino en el sitio de Chinikihá, Chiapas, México.

Restos arqueobotánicos de pino ocote recuperados de diferentes sitios del período Clásico Maya (300 - 900 d.C.) han demostrado diferentes usos que van desde rituales hasta abonos en los campos agrícolas. Nuestros resultados en la región de Palenque, en el sitio arqueológico de Chinikihá para el 620 d.C. sugieren que el uso del ocote era similar tanto en los palacios como en las unidades residenciales de los pobladores. Restos de madera carbonizada de ocote fueron identificados en contextos ceremoniales, funerarios y en los basureros de los patios residenciales. El uso moderno del ocote en Guatemala y en Chiapas es de gran importancia económica por la venta de rajas de ocote en lo mercados regionales. Estas son utilizadas como antorchas para iluminar de noche y para encender los fogones de cocina.

Palabras claves: Pinus, antracología, Palenque, Nahá.
\end{abstract}

Received: 29 August, 2016; Accepted: 15 February, 2017

\section{INTRODUCTION}

The ancient Maya inhabited the territories now known as Guatemala, Honduras, El Salvador, Belize and Mexico (Fig. 1). During the Classic Period (beginning $\mathrm{AD} 300$ ), the Maya courts played a central role in articulating the complex mosaic of networks of influence, prestige and alliances that would come to shape the political "landscape" in the North Western lowlands (INOMATA \& HousTON 2001). Ancient cities such as Palenque, Santa Isabel, Chinikihá, Pomoná, Bonampak, Yaxchilán and Piedras Negras, connected through many kinds of roads, causeways, sacbeob, paths, and sidewalks, exchanged such materials as textiles, ceramic, stone tools, food and drinks, cacao and other forest materials far away in Palenque's Hinterland (SILVA DE LA MORA 2008; LIENDO 2014, 2015). Trade goods were carried on the backs of porters called mecapaleros (NAVARRETE 1978). Ancient people of Palenque and Chinikihá exchanged forest resources that they were unable to procure in their region, like pine wood. Archaeological charred pine wood is found in the archaeological record. Was the pine a sacred plant reserved in ritual practices such as offerings, and food for the gods? Was the pine a material of prestige reserved only to the inhabitants of the palace? Or was, a plant used indiscriminately by all the Maya people in the whole region in domestic units of commoners as well as in the elite residences, to start the fire and light the night? The method we employed in Chinikihá was to sample different contexts: courtyards, burials and household refuse in the palace as in the domestic units. Collecting botanical remains from sediment using the flotation technique. We were interested in using charcoal analysis to understand the management and use of wood resources at Chinikihá, particularly non-local taxa (such as pine), and whether these practices were uniform throughout the site, or if they differed between different social classes, activities areas.

\section{THE ARCHAEOLOGICAL SITE}

\subsection{Location}

The archaeological site of Chinikihá is located in Chiapas México, near the foothills of the Sierra de Chiapas and Tabasco plains. The expanse of the civic-ceremonial core of Chinikihá, the density of its total population and the characteristics of its pattern of regional settlements, indicate the possibility that it was the head of an autonomous political entity, like Palenque, Piedras Negras and Pomoná (LIENDo et al. 2014). Chinikihá is $40 \mathrm{Km}$ away from its neighbor Palenque, and both are within high evergreen tropical forests dominated

${ }^{(1)}$ UNAM, Programa de Becas Posdoctorales en la UNAM, Becario del Centro Peninsular en Humanidades y en Ciencias Sociales CEPHCIS Mérida Yucatán Email: felipexate@gmail.com

${ }^{(2)}$ Universidad de Puerto Rico Email: auroramuriente@gmail.com 


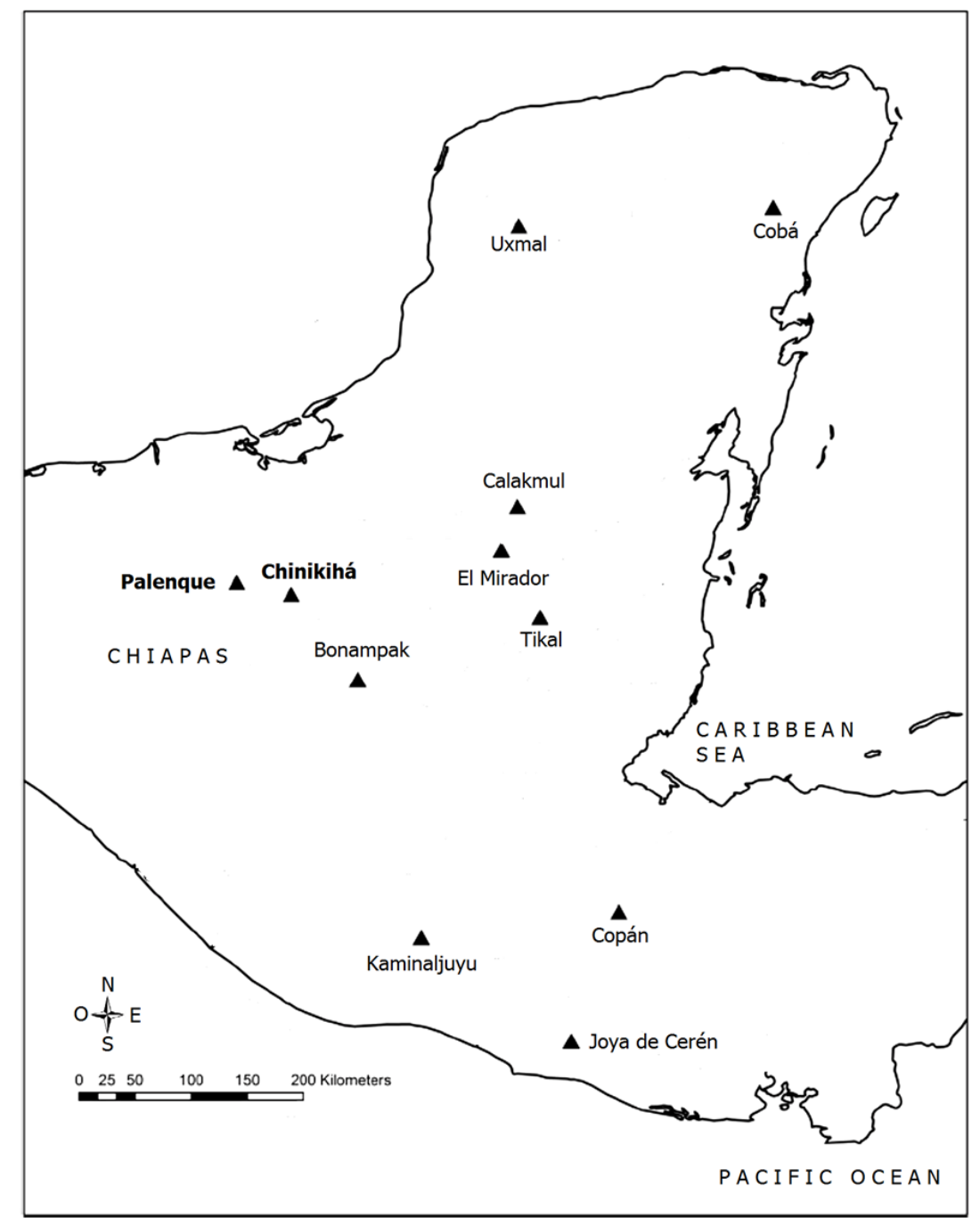

Fig.1. Maya Area.

Fig.1. Área maya.

by Canxán (Terminalia amazonia). The vegetation of Chiapas was classified by MIRANDA \& HERNÁNDEZ X (1963) as Selva alta perennifolia, and later as Bosque tropical perennifolio by Rzedowski (1978). The forest of the Palenque region is rich on Ficus, Psychotria and Piper (GÓMEZ-DOMÍNGUEZ et al. 2015). The secondary vegetation of this forest is characterized by the dominance of Trichospermum mexicanum, a soft tree which bark is used to make ropes and mecapales (MONTERO et al. 2016, VARELA \& TRABANINO 2016). South of this area are the mountains of Chiapas, which have a change in forest cover, starting at 800 meters high with montane cloud forests dominated by Tahté (Pinus maximinoi), like those surrounding the lacandon lagoons of Metzabok and Nahá.

\subsection{The Excavation}

Chinikihá possesses a great diversity of architectural structures, including a variety of civic- ceremonial structures, such as large plazas, a ball court, a palace and, residential patio groups (LIENDO et al. 2014). The sampling of archaeological sediments were carried out during the 2008 , 2010 and 2012 field seasons, concentrating mainly on, (a): Operation 114 (Op. 114) located behind the Palace of Chinikihá including both ritual and domestic contexts; (b): Operations 6, 111, 112, 117 and 143 of which include burial contexts and finally; (c): Operations 8, 115, 116, 134 and 158, located in courtyards (Fig. 2).

\section{MATERIALS AND METHODS}

In order to maximize the total amount of carbon recovered, different recovery techniques were carried out (PIQUÉ 1999). The recovery methods employed were as follows:

(a) Automatic recovery 2 liters of sediment by flotation using plastic buckets 20 liters capacity,

(b) Manual recovery (direct hand-picking) when sieving and screening; 

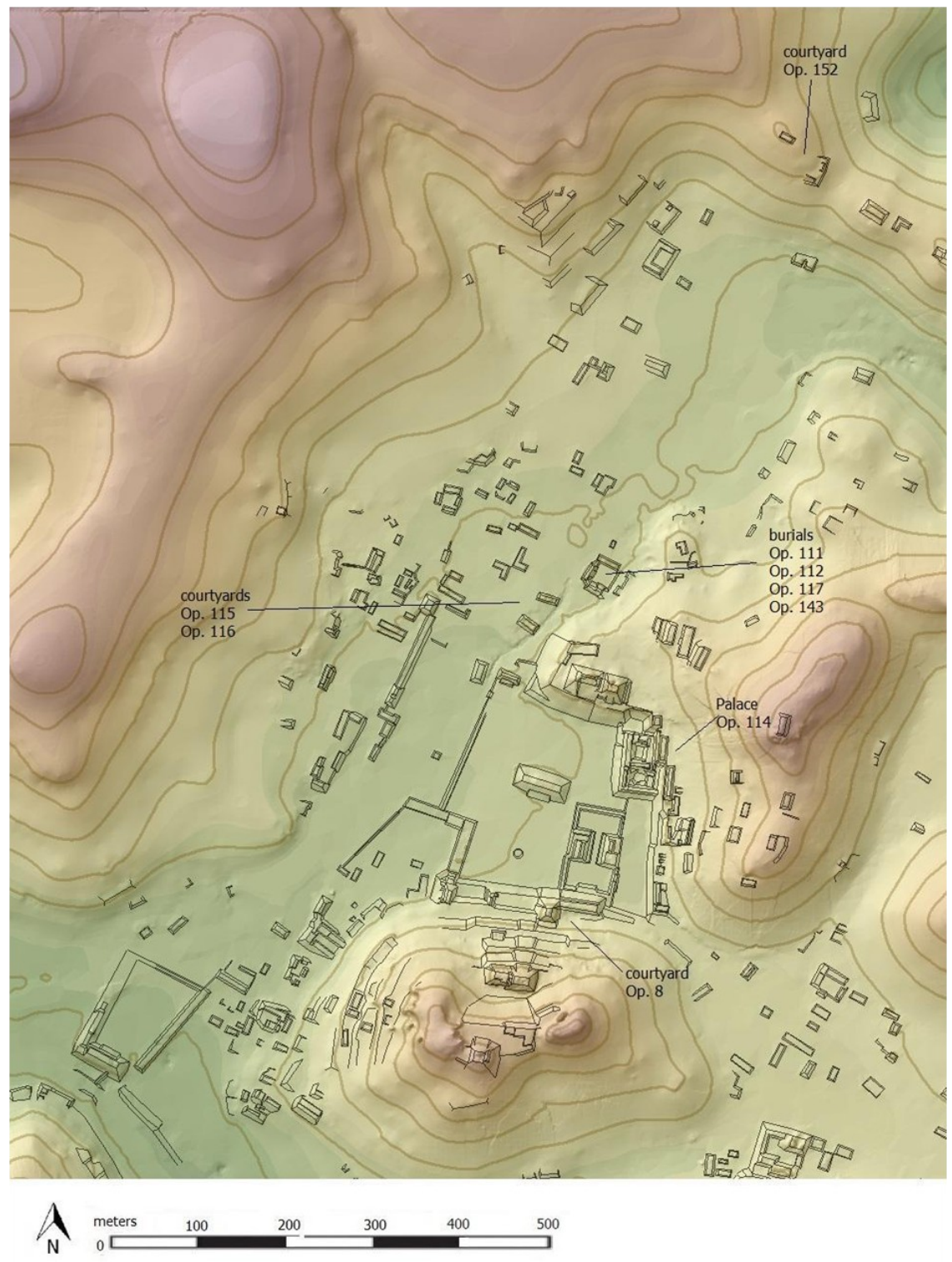

Fig. 2. Archaeological site of Chinikihá showing the operations where archaeobotanical analyses were conducted in courtyards, burials and behind the Palace.

Fig. 2. Sitio arqueológico de Chinikihá mostrando las operaciones donde análisis arqueobotánicos fueron realizados en patios, sepulturas y en el palacio.

(c) Manual recovery during excavation in the case of larger sized charcoal (more than $1 \mathrm{~cm}$ ).

We took 20 fragments of charcoal from each sample, following the methodology conducted in the anthracological analysis of Teotihuacan by (ADRIANO-MORÁn \& MCCLUNG DE TAPIA 2008). The identification was done by comparing the anatomy with our own reference collection of plants from the forests of El Petén (Guatemala) and Palenque (México), as well as with anatomical atlases (NARDI BERTI \& EDLMANN ABBATE 1992; BARAJAS et al. 1997; MILLER \& DÉTIENNE 2001). We could identify pine at the level of genus (Pinus sp.). Striations in the tracheids suggest compressed wood. It was not typical for all the assemblage (Fig. 3). Reaction wood of that type may indicate physical stress on the tree during growth, or indicate the selection of dead branches for firewood. At the instance, we are not able to have a determinant conclusion without the initial diameter.

Results of the dating evidence that Chinikihá was inhabited during the Classic Period (REBOLLO et al. 2014). Pine fragments were dated in the Laboratory of Arizona: Sample code AA-105569 14C age 1100 +- 30 years BP; Unmodeled Cal' AD (620660). The archaeobotanical remain of pine were photographed in the Laboratorio de Microscopía Electrónica y Microanálisis in Instituto de Geología at UNAM, using a SEM microscope (Fig. 3). 


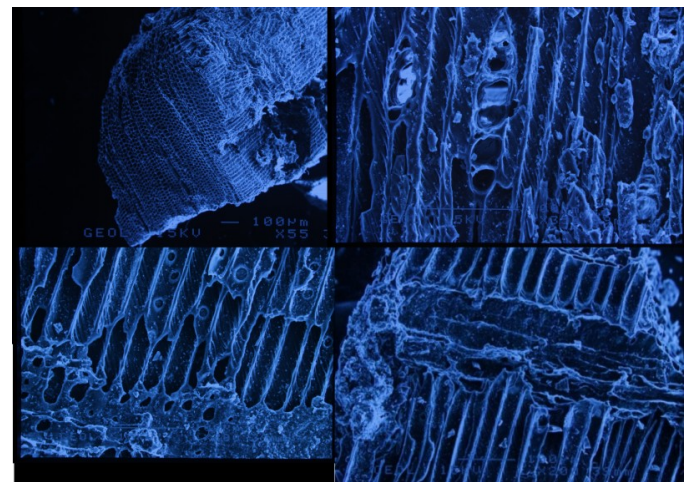

Fig. 3. Transversal section of charred pine (up and left), tangential longitudinal section (up and right), radial longitudinal section (down left and right). Scale: $100 \mu \mathrm{m}$.

Fig. 3. Sección transversal de pino carbonizado (arriba izquierda), sección longitudinal tangencial (arriba derecha), sección longitudinal radial (abajo izquierda y derecha). Escala: $100 \mu \mathrm{m}$.

\section{RESULTS}

1223 charcoal fragments were obtained from 86 samples of sediment extracted from the Palace, courtyards and burials. In this study we analyzed the presence-absence of the taxa identified to highlight those species present in the 3 contexts (palace, burials and residential courtyards). Pine is present in the trash deposit of the palace; only appears in one sample of the 5 burial sediments analyzed (Op. 117); and finally in two patios from 5 domestic units sampled (Op. 115 and 116).

Table 1. List of operations sediments analyzed in different contexts: trash deposit of the palace, burials and courtyards. Tabla 1. Lista de operaciones con sedimentos analizados en diferentes contextos: depósito de basura en el palacio, entierros y patios domésticos

\begin{tabular}{|c|c|c|}
\hline Operation No. & Context & $\begin{array}{c}\text { Presence/Absence of } \\
\text { archaeobotanical } \\
\text { remains of Pine }\end{array}$ \\
\hline 114 & $\begin{array}{c}\text { trash deposit of the } \\
\text { Palace }\end{array}$ & Present \\
\hline 6 & burial & Absent \\
\hline 111 & burial & Absent \\
\hline 112 & burial & Absent \\
\hline 117 & burial & Present \\
\hline 143 & burial & Absent \\
\hline 8 & courtyard & Absent \\
\hline 115 & courtyard & Present \\
\hline 116 & courtyard & Present \\
\hline 134 & courtyard & Absent \\
\hline 158 & courtyard & Absent \\
\hline
\end{tabular}

\section{INTERPRETATION}

Chinikihá villagers then had access to ocote pine to illuminate their kitchens nightly. The presence of the ocote pine (Pinus sp.) in all contexts indicates the widespread use of this plant resource in both elite and ceremonial contexts such as burial and everyday waste deposits in the residential courtyards throughout the periphery of the site. The pine species could correspond to coastal pine (Pinus caribaea) or mountain pine (Pinus oocarpa, Pinus maximinoi). Today people in the highlands still refer to ocote as the fastest fire starter (PERRY 1991). Maya people call ocote pine any pine tree that produce flammable pitch, without differentiation between various kinds of ocote pines. Ocote is an ethnotaxon, an ethnobotanical classification that include all the pines with resin (Pinus oocarpa, Pinus maximinoi, and Pinus caribaea). The ocote is refers to the presence of resin. Resin production is usually caused by cuts in the trunk repeatedly. But from where came the pine? Does it grow locally? Did they obtain it locally or throughout long distance exchange during prehispanic times? No pines are planted today in the lowlands of the Palenque region. The pine could come from this area in prehispanic times? If not cultivated in the site, ocote could be brought from the eastern side: Belizean coast, Quintana Roo coast, El Péten in Guatemala (from Usumacinta River to Tikal); where Pinus caribaea stands. Recently, Caribbean pine was identified at Lamanai in Belize (LENTZ et al. 2016). Another scenario could be that, ocote pine came from the highlands of the South (Sierra Madre de Chiapas). The first pine communities are observed today at 600 meters above sea level in Oxchuc, in the route from Palenque to San Cristobal de las Casas, and surrounding the lagoons of Nahá and Metzabok at $40 \mathrm{~km}$ from Chinikihá (Fig. 6 and 7).

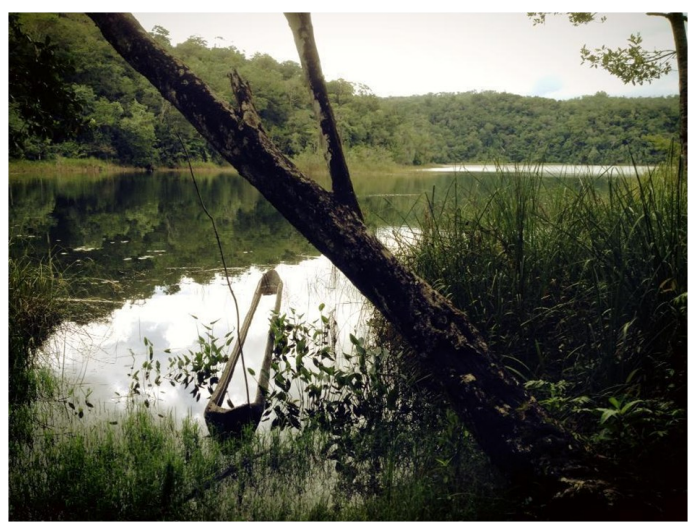

Fig. 6. Nahá lagoon with pine forest surrounding.

Fig. 6. Laguna Nahá, con bosque de pino en sus alrededores 


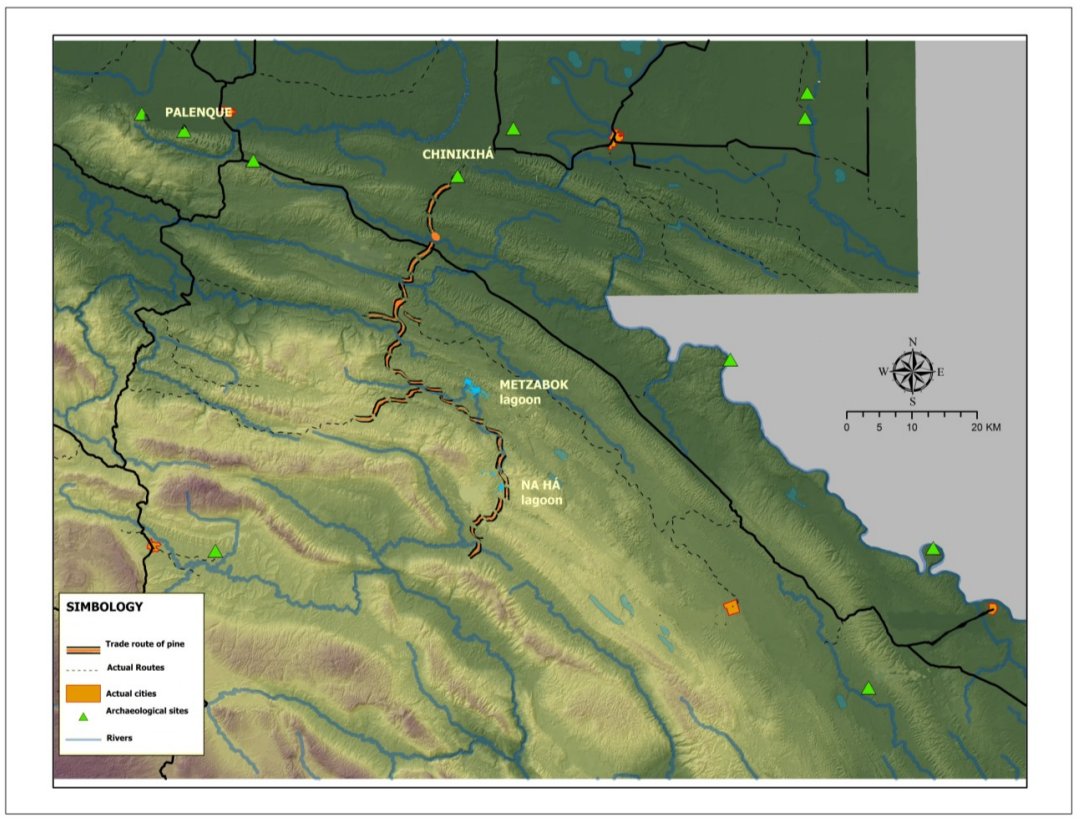

Fig. 7. Location of the archaeological site of Chinikihá showing the proposed prehispanic trade route of ocote pine from Nahá and Metzabok lagoons via Chancalá. Author: Javier López Mejía. Fig. 7. Ubicación del sitio arqueológico de Chinikihá, mostrando la ruta prehispánica propuesta de comercio del pino ocote desde las lagunas de Nahá y Metzabok vía Chancalá. Autor: Javier López Mejía.

In 2010 , up to $95.9 \%$ of the dwellings in the State of Chiapas had access to electricity, according to the Mexico National Institute of Statistics and Geography (INEGI 2010a, 2010b). According to INEGI, for that same year 1027957 of individual homes, out of a total of 1090914 had access to electricity, leaving 62957 without electricity.

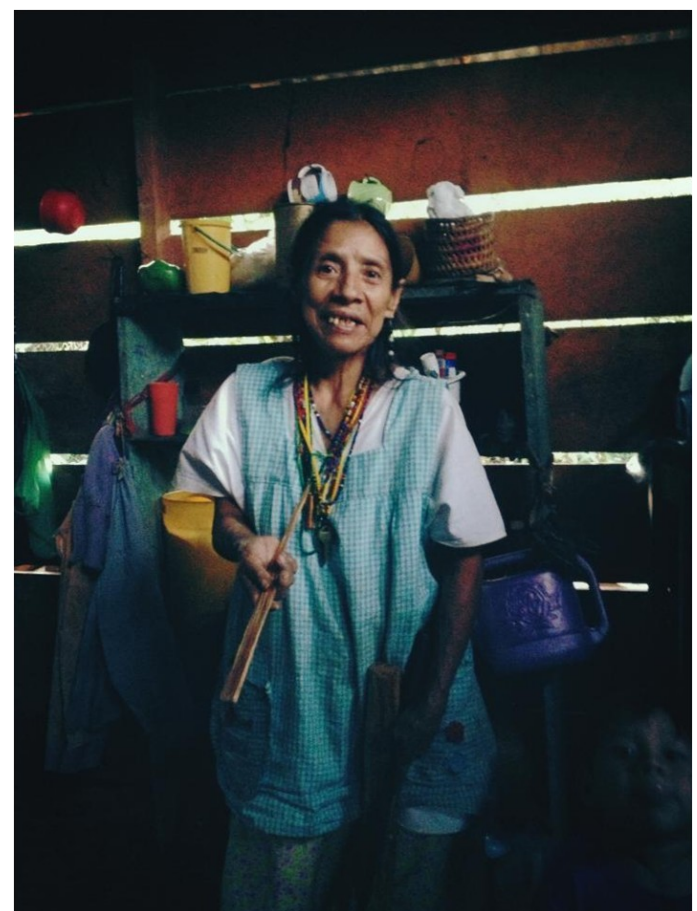

Fig. 8. Lacandona showing ocote stick and pine trunk. These are kept in the kitchen near the stove to turn it on.

Fig. 8. Lacandona mostrando raja de ocote y tronco de pino. Estos se mantienen en la cocina cerca del fogón para encenderlo.
These families without access to electricity are still lighting their houses with fire generated from pine tar/resin, and many of those households that do have access to electricity still use wooden stoves to cook because of the high gas and electricity prices.

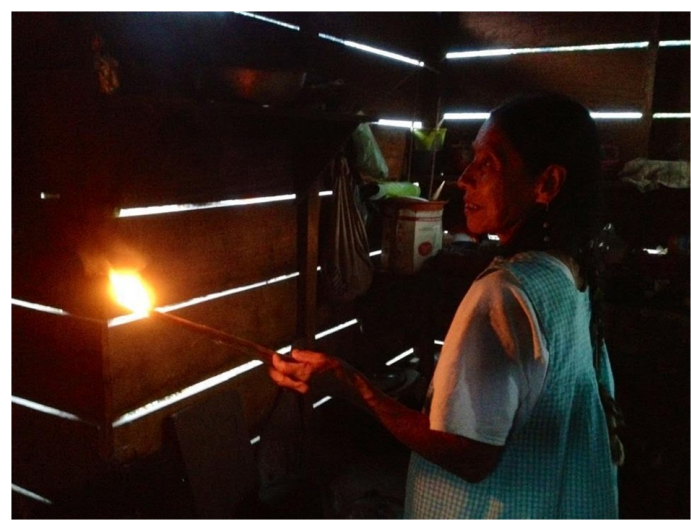

Fig. 9. Lacandona woman lighting the kitchen with a ocote stick.

Fig. 9. Lacandona alumbrando la cocina con un ocote.

At night, the light coming from many rural houses in Chiapas has a distinguishable red glow that comes from the intense fire produced when burning the pine tar/resin known as ocote. This is the flame that fires up the stoves to prepare food and the bon fires that keep families warm during the months of heavy rain. Ocote has also been used for rituals or ceremonial activities, but nowadays wax candles have increasingly substituted it. Ocote is lit with matches and its function is to keep the 
fire's flame lit while the humid firewood is warmed and readies to catch fire.

In the markets located at the elevated parts of Chiapas, a handful of ocote, comprised of three pine sticks, currently costs two Mexican pesos. Archaeobotanical remains from the Classic Maya period from various excavations demonstrate widespread use of the ocote ranging from the Maya lowlands to the highlands, and occasionally in places far away from the pine forests (MIKSICEK 1988; RAMÍREZ-SOSA et al. 1996; LENTZ 1991a; 1991b; 1994; LENTZ et al. 1996; TRABANINO 2009).

Table 2. Remains of charred wood of Pinus recovered in lowlands archaeological sites far away from pine forests.

Tabla 2. Restos de madera carbonizada de Pinus recogidos en sitios arqueológicos lejanos de bosques de pino.

\begin{tabular}{|c|c|c|c|}
\hline Site & Dates & Fases & Reference \\
\hline $\begin{array}{l}\text { Dos Pilas, } \\
\text { Guatemala }\end{array}$ & $?$ & Classic & LENTZ 1994 \\
\hline $\begin{array}{l}\text { El Mirador, } \\
\text { Guatemala }\end{array}$ & $\begin{array}{c}\text { AD 850- } \\
1000\end{array}$ & Posclassic & $\begin{array}{l}\text { TRABANINO } \\
2009\end{array}$ \\
\hline $\begin{array}{l}\text { Yarumela, } \\
\text { Honduras }\end{array}$ & $1000 \mathrm{BC}$ & Formative & $\begin{array}{l}\text { RAMÍREZ- } \\
\text { SosA et al. } \\
1996\end{array}$ \\
\hline $\begin{array}{l}\text { Copán, } \\
\text { Honduras }\end{array}$ & $\begin{array}{c}400 \mathrm{BC}-\mathrm{AD} \\
900\end{array}$ & Preclassic & LENTZ 1991a \\
\hline $\begin{array}{c}\text { Naco, } \\
\text { Honduras }\end{array}$ & $?$ & $?$ & LENTZ 1991b \\
\hline $\begin{array}{c}\text { Joya de } \\
\text { Cerén, El } \\
\text { Salvador }\end{array}$ & AD 585-600 & Classic & $\begin{array}{c}\text { LENTZ et al. } \\
1996\end{array}$ \\
\hline $\begin{array}{l}\text { Cihuatán, } \\
\text { El Salvador }\end{array}$ & $\begin{array}{c}\text { AD 900- } \\
1200\end{array}$ & Posclassic & $\begin{array}{c}\text { MIKSICEK } \\
1988\end{array}$ \\
\hline
\end{tabular}

This suggests that there was a considerable exchange network for the ocote and, given the amount of carbonized pine remains found, it is estimated that it was an accessible good. In this and other investigations, ethnography has helped with the rebuilding of the meaning of ocote in the Mayan history. "By integrating the archaeobotanical data on pine with multiple lines of analogy from ethnohistory, ethnography, iconography, and epigraphy, we suggest that pine was a recognized component of ritual activities" (MOREHART et al. 2005: 256).

During our visit to the Nahá community we were able to go inside a typical family kitchen. It was a big room made with wooden panels and a zinc ceiling where the women and children spent countless hours each day. The lacandon women, who were in charge of the domestic space, zealously guard the fire, considered sacred by them. They use firewood, ocote and air so the flame is kept ablaze permanently. Two stoves were there simultaneously lit. One of them, where beans and tortillas were being cooked, stood approximately one meter tall over a dirt-filled wooden box (Fig. 11). The second one was located inside a carved hole in the dirt floor at the center of the kitchen space. This one was used to light the dark space and to warm the heavier pots.

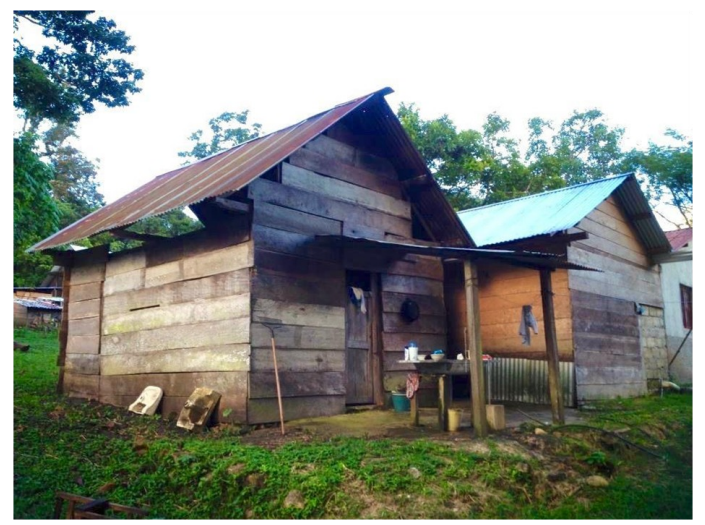

Fig. 10. Houses in Nahá.

Fig. 10. Casas en Nahá.

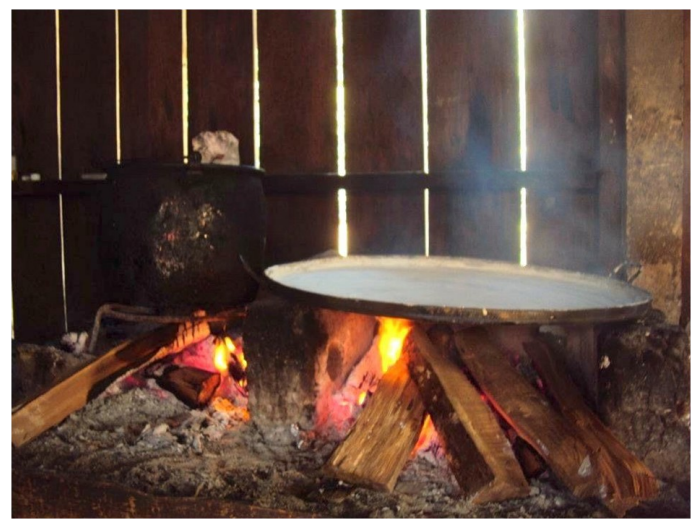

Fig. 11. Stove in a kitchen at Nahá.

Fig. 11. Fogón en una cocina de Nahá.

The pine's resin is fundamental to keep the flames ablaze. Small ocote sticks are frequently added to the bonfire, sparkling as they are burnt and sending myrrh-like aroma through the air. This gives the impression of transforming the kitchen into a temple where the community feast is cooked. A lacandon woman, self-identified as a "shaman", lit an ocote stick with matches and placed it in the bonfire to demonstrate how it is used (Figs. 8 and 9). The ocote she used came from the hillside of the Nahá lagoon, which is one of the main pine sources of the region.

\section{CONCLUSIONS}

The ocote was used in ancient times to light and make fire, as today. Pine was also used in rituals for its aroma and for medicine. Slits high pine 
resin, can be exploited as ocote. The ocote correspond to any kind of pine species with high contents of resin. The ocote has a very important ritual use; it is omnipresent in the offerings of $\mathrm{Zi}$ nacantán, symbolizing the corn, food for the Gods (VoGT 1993). But this ritual use is not unique and principal, and not reserved only for the inhabitants of the most prestigious residential areas. Charred remains of pine were identified in the dooryards of the domestic units too. These suggest that pine was a main element of the kitchen, present in the daily use of every family. Finally, Chinikihá is a modest archaeological site. Elsewhere from Palenque to Usumacinta River, all the inhabitants of this region might have used pine wood daily, from the grand palace to the most modest domestic group.

\section{ACKNOWLEDGMENTS}

The Authors wish to thank María Martín-Seijo for the organization of the International meeting in Braga: Wood and Charcoal, approaches from Archaeology, Archaeobotany, Ethnography and History. To Claudia Manuel, Pedro Dinis, and anonymous reviewers, for the recommendations on the manuscript. To Lisa Johnson (University of Berkeley, California) for the english revision. To Coordinación de Humanidades, Programa de Becas Posdoctorales en la UNAM, Centro Peninsular en Humanidades y en Ciencias Sociales - UNAM sede Mérida Yucatán. Thanks to Dr. Rodrigo Liendo, Dr. Flavio Silva (UC-MEXUS) and Dra. Noemí Rebollo for the radiocarbon dating. Silvia Angeles García and Margarita Reyes Salas (Instituto de Geología, UNAM) for the technical assistance with the Scanning Electron Microscope. To Atasta Flores, Arianna Campiani \& Javier López Mejía for the elaboration of the map of Chinikihá.

\section{BIBLIOGRAPHY}

Adriano Morán, C. \& MCClung DE TAPIA, E. 2008. Trees and shrubs: the use of wood in prehispanic Teotihuacan. Journal of Archaeological Science, 35: 2927-2936.

Barajas Morales, J.; Ángeles, G. \& Solís, R. 1997. Anatomía de maderas de México: especies de una selva alta perennifolia I. Publicaciones especiales 16. México, Instituto de Biología UNAM.

Gómez Domínguez, H.; Pérez Farrera, M. A. ; Espinosa JiMÉNEZ, J. A. \& MÁRQUEZ-REYNOSO, M. I.. 2015. Listado florístico del Parque Nacional Palenque, Chiapas, México. Botanical Sciences 93(3): 559-578.

INEGI 2010a Instituto Nacional de Estadísticas y Geografia. Porcentaje de viviendas con electricidad, www.inegi.org.mx, México.

INEGI 2010b Instituto Nacional de Estadísticas y Geografía. Viviendas particulares habitadas que disponen de energía eléctrica (Viviendas), www.inegi.org.mx, México.

InOMATA, T. \& Houston S. (Eds.). 2001. Royal Courts of the Ancient Maya. Westview, Boulder.

LENTZ, D. L. 1991a. Maya diets of the rich and poor: Paleoethnobotanical evidence from Copán. Latin American Antiquity 2:269-287.

LENTZ, D. L. 1991b. Archaeobotanical remains from Naco, Valley, Honduras. Ms. on file, New York Botanical Garden Harding Laboratory.
LENTZ, D. L. 1994. Paleoethnobotanical evidence for subsistence practices and other economic activities in the Petexbatún region during the Classic period. Paper presented at the 93d American Anthropological Association Meeting, Atlanta.

LentZ, D. L.; BeAudry Corbett, M.; Reyna DE Aguilar, M.L. \& KAPLAN, L. 1996. Food-stuffs, forests, fields, and shelter: A paleoethnobotanical analysis of vessels contents from the Cerén site, El Salvador. Latin American Antiquity 7:247-262.

Lentz, D. L.; Graham, E.; Vinaja, X.; Slotten, V. \& JAIN, R. 2016. Agroforestry and ritual at the ancient Maya center of Lamanai. Journal of Archaeological Science: Reports, 8: 284-294.

Liendo Stuardo, R.; López Mejía, J. \& Campiani, A. 2014. The Social construction of Public Space at Palenque and Chinikihá, México. In: K. Tsukamoto \& T. Inomata (Eds.), Mesoamerican plazas: arenas of community and power, Tucson, The University of Arizona Press: 108-120.

LIENDO STUARDO, R. 2014. Una revisión arqueológica de la historia de Palenque durante los siglos VIII y IX (fases Murciélagos-Balunté). Cuicuilco, 21(60): 6882.

Liendo Stuardo, R. 2015. Canchas de juego de pelota en la región de palenque, chiapas: representación y política. Anales de Antropología, 49(1): 135-155,

MiKSICEK, C. H. 1988. Man and environment at Cihuatán. In J. H. Kelly (Ed.): Cihuatán, El Salvador: A study in intrasite variability. Nashville: Vanderbilt University Press, pp. 149-155.

MilleR, R.B. \& DÉTIEnNE, P. 2001. Major timber trees of Guyana. Wood Anatomy. Netherlands, Tropenbos International.

MirandA, F. \& Hernández X., E. 1963. Los tipos de vegetación de México y su clasificación. Boletín de la Sociedad Botánica de México 29:1-179.

Montero López, C. 2011. From ritual to refuse: faunal exploitation by the elite of Chinikihá, Chiapas, during the Late Classic Period. Unpublished Ph.D. dissertation, School of Historical and European Studies, La Trobe University, Australia.

Morehart, C.T.; Lentz, D. L. \& Prufer, K. M. 2005. Wood of the Gods: The ritual use of pine (Pinus spp.) by the ancient Lowland Maya. Latin American Antiquity, 16(3): 255-274.

NARdi Berti, R. \& Edlmann Abbate, M. L. 1992. Legnami Tropicali importati in Italia: Anatomia $e$ Identificazione. Vol. 2. America Latina. Firenze, CNR.

NAVARRETE, C. 1978. The Prehispanic system of communication between Chiapas and Tabasco. In: Mesoamerican Communication Routes and Cultural Contact. Provo, Brigham Young University: 75-106.

PIQUÉ I HUERTA, R. 1999. Producción y uso del combustible vegetal: una evaluación arqueológica, Treballs d'Etnoarqueología 3. Madrid, Universidad Autónoma de Barcelona.

Perry, J. P. 1991. The pines of Mexico and Central Ameri$c a$. Timber Press Inc. Portland, Oregon.

RÁMIREZ-SOSA, C.R.; GRISCOM, B. W. \& LENTZ, D.L. 1996 Investigaciones paleoetnobotánicas del período formativo en el sitio de Yarumela, Honduras. Yaxkin 14(1,2): 74-95. 
Rebollo, N. R.; Morales, P.; Liendo Stuardo R.; NúÑEZ, L. F.; TRABanino, F. \& Negrete, S. 2014. Preservación de huesos y carbones en sepulturas rituales de Chinikihá. Paper presented at the IV Congreso Latinoamericano de Arqueometría, México.

RzedowsKi, J. 1978. Vegetación de México. Limusa Wiley, México, D.F.

Silva DE LA Mora, F. 2008. Sicix Bäbih, caminos en las Tierras Bajas Noroccidentales. Una propuesta de rutas de comunicación. Tesis de Licenciatura, México, Escuela Nacional de Antropología e Historia.
Trabanino, F. 2009. Vegetación y Ruinas Mayas. Evidencias paleoetnobotánicas de la Pirámide la Danta,en el Clásico Tardío Terminal (850-1000 D.C.), El Mirador, Petén, Guatemala. Informe final SRE México, SEGEPLAN Guatemala. RAINPEG Fares Foundation.

Vogt, E. Z. 1993. Tortillas for the Gods: A Symbolic Analysis of Zinacanteco Rituals. Norman and London, University of Oklah 